\title{
The Impact of the New Rural Pension Scheme on Retirement Sustainability in China: Evidence of Regional Differences in Formal and Informal Labor Supply
}

\author{
Benxi Lin ${ }^{1}$, Zongjian Lin ${ }^{2}$, Yu Yvette Zhang ${ }^{3,4, *}$ and Weiping Liu ${ }^{1}$ \\ 1 School of Economics, Fujian Agriculture and Forestry University, Fuzhou, Fujian 350002, China; \\ bxlin@126.com (B.L.); lwp789326@126.com (W.L.) \\ 2 Zhou Enlai School of Government, Nankai University, Tianjin 300071, China; zongiian_lin@foxmail.com \\ 3 School of Management, Fujian Agriculture and Forestry University, Fuzhou, Fujian 350002, China \\ 4 Department of Agricultural Economics, Texas A\&M University, College Station, TX 77843, USA \\ * Correspondence: yzhang@tamu.edu
}

Received: 3 October 2018; Accepted: 15 November 2018; Published: 23 November 2018

\begin{abstract}
This paper evaluates the effect of China's New Rural Pension Scheme (NRPS) on the retirement sustainability in forms of formal labor supply and informal labor supply in terms of care of grandchildren, using data from China Health and Retirement Longitudinal Study (CHARLS). We explore the regional differences of the NRPS effect on labor supply between the West and the other regions of China. Our analysis shows that rural Western China has a more severe problem of "ceaseless toil" compared to the rest of the country. We find that NRPS improves the "ceaseless toil" situation of the Chinese rural elderly especially in Western China. Our results suggest the need to increase the amount of NRPS payment, and to develop a region-specific pension programs in China.
\end{abstract}

Keywords: China Rural Pension Scheme; retirement sustainability; labor supply; grandchildren care; Western China; ceaseless toil

\section{Introduction}

Labor supply behavior is an important factor in the sustainability of the retirement system [1,2]. The retirement pattern of the Chinese elderly in rural regions has been described as "ceaseless toil", due to the fact that most elderly in rural China continue to work until they are no longer physically capable of labor [3-6]. One of the causes of the "ceaseless toil" situation was the lack of an established rural pension system. Self-labor income and financial transfer from adult children have been the main income sources for the rural elderly [7-9]. However, since the Chinese economic reform in the 1980s, a large portion of the young and middle-aged rural population migrated to cities, leaving the elderly living on their own. Moreover, the One Child Policy, which was implemented in 1980, has significantly reduced the labor force and weakened a family's ability to support the elderly. Therefore, the traditional Chinese family pattern of old-age provision is no longer sustainable, resulting in many of the elderly relying increasingly on their own labor [5]. With the aim of providing income support for the rural elderly and release them from the "ceaseless toil", the Chinese government launched the New Rural Pension Scheme (NRPS) in 2009 and this program has covered all regions of rural China since 2012 [10]. In addition to the NRPS program, the Urban Resident Social Pension (URSP) Program covering the urban residents was implemented in 2011. The NRPS and URSP were further merged at the policy level of central government in 2014 and became the Government and Institution Pension (GIP) Program to provide greater social equality [11]. In this study, we used the data from the China 
Health and Retirement Longitudinal Survey (CHARLS) in 2013, when these two pension systems were still operating in parallel. Our objective is to evaluate the effect of NRPS on the retirement sustainability of Chinese rural elderly.

Several studies used the data from CHARLS to examine the impacts of NRPS on the rural elderly's labor activities including agricultural work, wage-earning work, self-employed activities, and unpaid family business work, but the conclusions were often conflicting. For example, Ning et al. [6] found that NRPS had no effect on the labor participation of the rural elderly. In contrast, Huang et al. [12] and Chen et al. [13] suggested that NRPS decreased the rural elderly's labor participation and increased their probability of retirement. Shu [14] broke down the labor supply into agricultural and nonagricultural labor supply and found that NRPS decreased the working hours of the rural elderly mainly in the agricultural work. In addition to the formal labor activities, the majority of China's rural elderly take up the work of caring for their grandchildren so that their children are willing to support them later on in life [5]. These activities increase the labor intensity and economic pressure of the elderly but may also have a negative impact on their health [15]. Therefore, several studies have suggested that time spent caring for grandchildren is an important factor when evaluating NRPS's impact on the rural elderly's wellbeing $[13,14]$. In our study, we evaluated the effect of NRPS on labor supply of the rural elderly in forms of both formal labor work in terms of agricultural practices and off-farm employment, and informal labor work in terms of the time spent caring for grandchildren.

Regional difference is another important factor that should be considered in the social pension scheme [10]. Significant regional gap in income and economic growth exist in China with Western China traditionally lagging behind the rest of the country $[14,16]$. The NRPS is a voluntary program that allows participants to receive a pension, starting age 60 after 15 years of contributions. Participants aged 45 or over when enrolling in NRPS will be required to make a lump-sum payment to cover the shortfall years. The pension includes two components: a basic pension component, and an individual account with matching contributions. The basic pension varies across different regions according to local government policies (China Statistical Yearbook 2015, http:/ / www.stats.gov.cn/tjsj/ndsj/ 2015/indexeh.htm). For example, the basic pension level for rural residents in Beijing is $280 \mathrm{CNY}$ per month [17] and 370 CNY per month in Shanghai (http:/ / www.12333sh.gov.cn/201412333/xxgk/ flfg/gfxwj/zrsxwj/201405/t20140507_1182703.shtml). However, in Western China, the highest basic pension level is only 85 CNY per month (Qinghai Province http: / www.gov.cn/fwxx/sh/2012-06/ 19/content_2164434.htm). China's central government fully finances the basic pension in the Western regions but only finances up to $50 \%$ of basic pension in other regions, due to significant regional income inequalities and regional differences in economic development. Moreover, matching and management of the individual accounts are determined by local governments that vary across different regions [18]. Therefore, it is important to investigate the regional differences in NRPS program and its impacts on social welfare in different regions of China.

To our knowledge, our study is the first research to look at the regional differences of the impact of NRPS on rural elderly's formal and informal labor supply. We found that NRPS improves the "ceaseless toil" situation of the Chinese rural elderly, hence contributing to the sustainability of the rural retirement system in China. Moreover, our results show a very different pattern between Western China and other parts of the country.

\section{Data and Variables}

The data used in our research came from 2013 CHARLS, which is a biennial national survey of Chinese residents in 150 counties/districts and 450 villages/residential committees. We focus on the rural residents. Our study included rural residents aged between 50 and 70, with 6504 observations for formal labor analysis, and 3119 observations for informal labor analysis. The number of observations in the informal labor analysis is smaller than that of formal labor analysis, since for each household, only one person is surveyed about the time spent caring grandchildren. Formal labor supply, in our study, is calculated as total weekly labor hours in activities including work on the farm, off-farm work for a wage, 
and work for the household's off-farm business. Informal labor supply is calculated as weekly hours of taking care of grandchildren under the age of 16 . We define the Western regions of China according to the "Western Development Program" of the Chinese government (http:/ / www.chinawest.gov.cn), which includes 6 provinces (Gansu, Guizhou, Qinghai, Shaanxi, Sichuan, and Yunnan), 5 autonomous regions (Guangxi, Inner Mongolia, Ningxia, Tibet, and Xinjiang), and 1 municipality (Chongqing), whereas all the other regions are defined as non-Western regions. The descriptions of the variables used in the study and the summary statistics are presented in Table 1.

Table 1. Definition of Variables and Descriptive Statistic.

\begin{tabular}{|c|c|c|c|}
\hline Variable & Definition & Mean & SD \\
\hline Informal labor & Hours of taking care of grandchildren weekly & 29.513 & 5.368 \\
\hline $\mathrm{Ti}$ & If age $\geq 60(=1)$ & 0.498 & 0.500 \\
\hline Pension & The amount of NRPS payment (CNY) & 38.383 & 98.845 \\
\hline Age & Age & 59.305 & 5.478 \\
\hline Married & Married and lives with spouse $(=1)$ & 0.841 & 0.366 \\
\hline Health & Health status $(1=$ Excellent; $2=$ Very good; $3=$ Good; $4=$ Fair $;=$ Poor; $6=$ Very poor $)$ & 4.037 & 0.949 \\
\hline Land & Total land area including plough, forest land, meadow, pool $(\mathrm{mu})$ & 12.635 & 85.447 \\
\hline Income & Weekly household income (CNY) & 305.202 & 782.086 \\
\hline West & Western China $=1$ & 0.265 & 0.441 \\
\hline
\end{tabular}

Notes: The data is from CHARLS, 2013-2014.

\section{Methods}

We employ the regression discontinuity method (RD) to examine the NRPS effect on the rural elderly's labor supply, see $[7,19,20]$. A standard fuzzy RD design is applied because not all rural elderly aged 60 or older receive NRPS pension. The number of elderly aged 60 or older who did not receive NRPS pension in our sample is 501, which accounts for 15 percent of all elderly aged 60 or older in the analysis. Moreover, some elderly began receiving pension before the age of 60 , as they participated in the Old Rural Pension Scheme (ORPS), which was implemented in 1992 and under which participants could start receiving pension at the age of 55 or 50 depending on their regions. Those enrolled in ORPS were automatically enrolled in the NRPS. The elderly who received the pension before age of 60 account for $1.29 \%$ of our sample. Figure 1 illustrates the relationship between probability of receiving NRPS pension and age and shows a discontinuous jump at age 60 .

The first stage model is set up as

$$
\operatorname{Pr}\left(\operatorname{NRPS}_{i}=1\right)=F\left(\alpha_{0}+\alpha_{1} \operatorname{Ag}_{i}^{e}+\pi T_{i}+\gamma_{i}^{\prime} X_{i}+v_{i}\right)
$$

where $\operatorname{Pr}(N R P S i=1)$ represents the probability of receiving NRPS pension, and $T_{i}$ is the treatment dummy, which is 1 when the individual is older than $60 . X_{i}$ is a vector of control variables including income, gender, marriage status, health condition, education level, and land acreage. The second stage model analyzes the effect of NRPS status on weekly labor supply hours $\left(Y_{i}\right)$

$$
Y_{i}=\gamma_{0}+\gamma_{1} \operatorname{Pr}\left(\operatorname{NRPS}_{i}=1\right)+A g e_{i}+\beta_{i} X_{i}+\varepsilon_{i}
$$




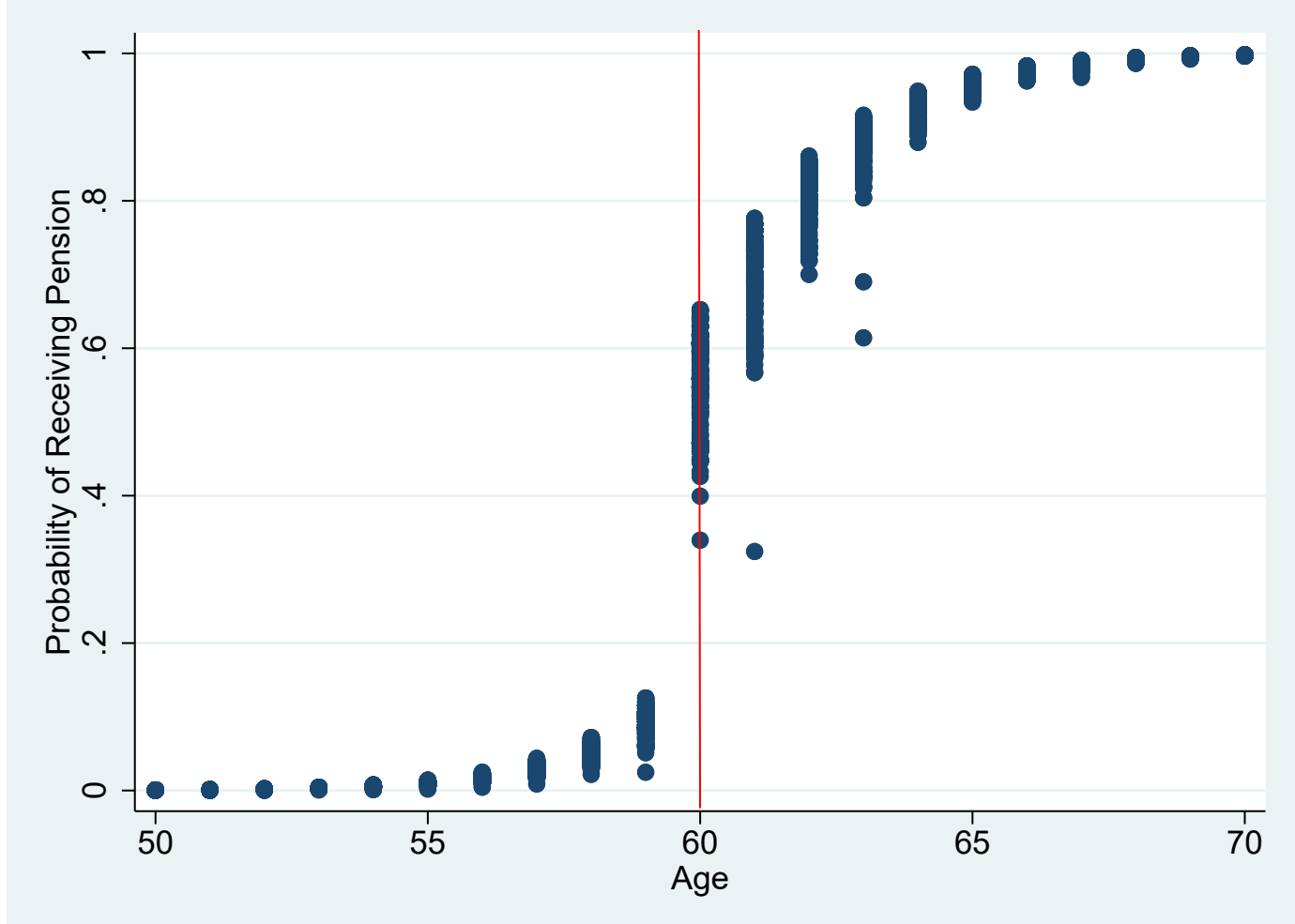

Figure 1. Relationship of Age and Probability of Receiving NRPS Pension.

\section{Results and Discussion}

We first estimate the effect of NRPS on labor supply in both formal labor work and informal labor work of rural elderly, by pooling the samples from both West and non-West regions together (Table 2). The amount of pension payment decreases the informal labor supply significantly but has no effect on formal labor supply. Unsurprisingly, females contribute less to formal labor, but more to informal labor compared to males. Furthermore, the elderly in the West regions contribute significantly more to formal labor than non-Western regions, implying that Western China has a more severe problem of "ceaseless toil" compared to the rest of the country. Formal labor decreases with worse health condition. In addition, married elderly tend to provide more formal labor.

To study the regional differences in the effect of NRPS, we further divide our sample into two region groups: the Western regions and non-Western regions. The results are presented in Table 3, which displays very different regional patterns. As people age, their formal labor supply decreases significantly in the non-Western regions, yet not in the Western regions. This result again implies the "ceaseless toil" situation in Western rural China. The probability of receiving NRPS pension can significantly decrease the formal labor participation in Western China by more than $7 \mathrm{~h}$ per week but not in other regions. We thank an anonymous reviewer for his/her great insights in addressing this important result. Participation in the informal labor supply decreases significantly as people age in both regions. Furthermore, increasing the amount of pension payment significantly decreases the informal labor supply in the non-Western regions, and every $100 \mathrm{CNY}$ can reduce informal labor supply by $1.2 \mathrm{~h}$ per week. However, this effect is not evident in the Western regions.

It is worthy to note the low R-square in the results due to the high amount of unexplainable variability in the observations, which is a common problem in many labor studies, e.g., [21-27]. Nevertheless, even when R-squared is low, low $p$-values still indicate a real relationship between the significant predictors and the response variable. There may also be potential multicollinearity and endogeneity problems in the estimation that need to be addressed in the future study. 
Table 2. NRPS Effects on Formal and Informal Labor Supply.

\begin{tabular}{|c|c|c|}
\hline & Formal Labor $(n=6504)$ & Informal Labor $(n=3119)$ \\
\hline \multicolumn{3}{|c|}{ First Stage Estimates [Dependent Variable: $\operatorname{Pr}(N R P S=1)$ ] } \\
\hline Age $>60$ & $2.041^{* * *}(0.000)$ & $2.079^{* * *}(0.000)$ \\
\hline Pseudo $R^{2}$ & 0.681 & 0.679 \\
\hline \multicolumn{3}{|c|}{ Second Stage Estimates [Dependent Variable: Weekly labor hours] } \\
\hline $\operatorname{Pr}(N R P S)$ & $\begin{array}{l}-2.076 \\
(0.248)\end{array}$ & $\begin{array}{c}4.722 \\
(0.411)\end{array}$ \\
\hline Pension & $\begin{array}{l}-0.001 \\
(0.769)\end{array}$ & $\begin{array}{c}-0.012 * * \\
(0.029)\end{array}$ \\
\hline Age & $\begin{array}{c}-0.584^{* * *} \\
(0.000)\end{array}$ & $\begin{array}{c}-1.356^{* * *} \\
(0.003)\end{array}$ \\
\hline Gender & $\begin{array}{c}-8.830 * * * \\
(0.000)\end{array}$ & $\begin{array}{c}6.380 * * * \\
(0.002)\end{array}$ \\
\hline Education & $\begin{array}{l}-0.273 \\
(0.752)\end{array}$ & $\begin{array}{c}0.156 \\
(0.957)\end{array}$ \\
\hline Married & $\begin{array}{c}2.782^{* * *} \\
(0.001)\end{array}$ & $\begin{array}{c}3.433 \\
(0.197)\end{array}$ \\
\hline Health & $\begin{array}{c}-0.759 * * * \\
(0.003)\end{array}$ & $\begin{array}{c}0.742 \\
(0.428)\end{array}$ \\
\hline Income & $\begin{array}{l}0.001^{* *} \\
(0.038)\end{array}$ & $\begin{array}{c}0.003^{* * *} \\
(0.004)\end{array}$ \\
\hline Land & $\begin{array}{c}0.001 \\
(0.839)\end{array}$ & $\begin{array}{l}-0.013 \\
(0.071)\end{array}$ \\
\hline West & $\begin{array}{c}4.194^{* * *} \\
(0.000)\end{array}$ & $\begin{array}{c}3.590 \\
(0.116)\end{array}$ \\
\hline $\mathrm{R}^{2}$ & 0.060 & 0.020 \\
\hline
\end{tabular}

Notes: * significant at $10 \%$; ** significant at $5 \%$; *** significant at $1 \% . p$-values are presented in parentheses.

Table 3. The Second Stage Model Results for Regional Model of NRPS Effects on Labor Supply.

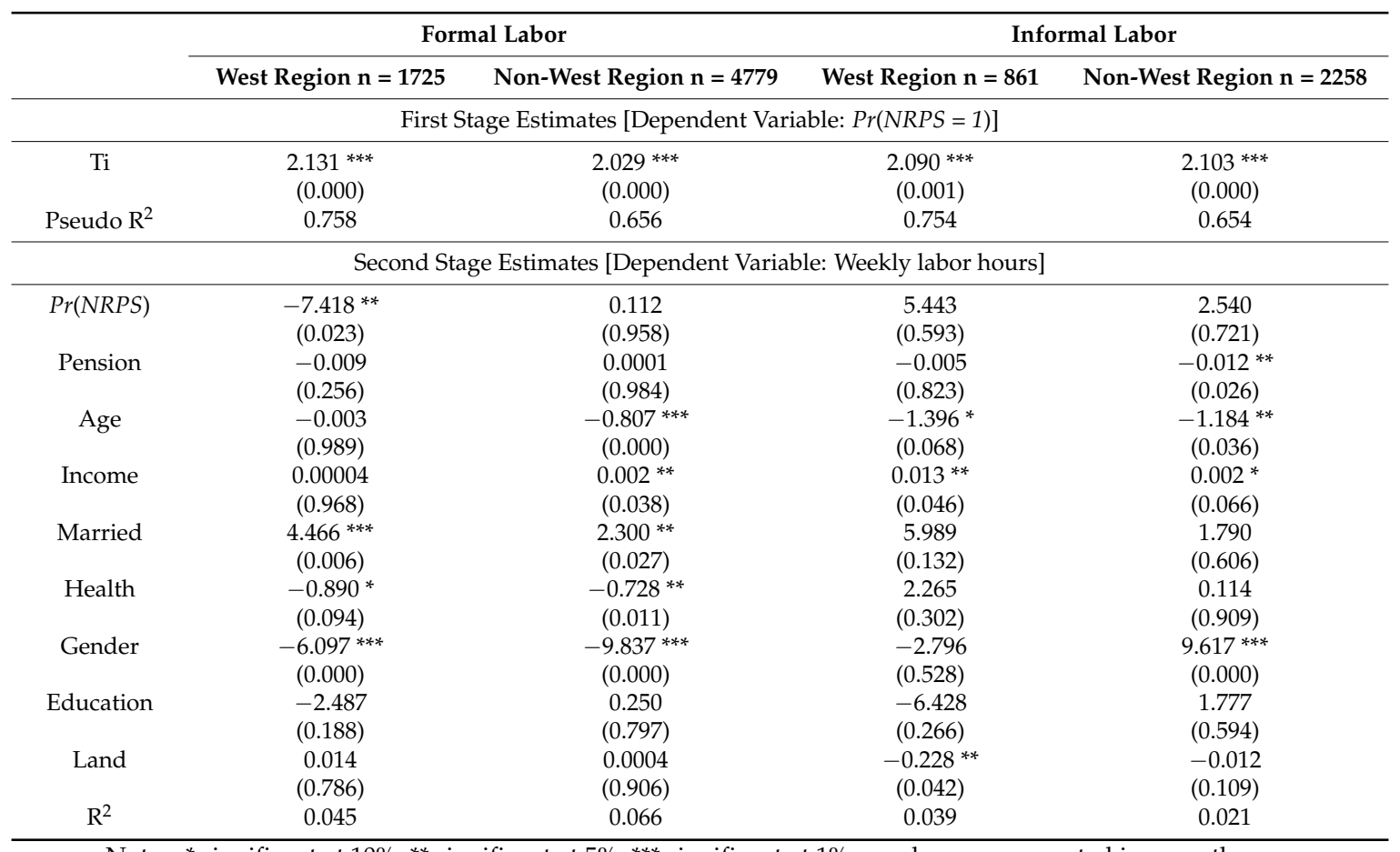

Notes: ${ }^{*}$ significant at $10 \% ;{ }^{* *}$ significant at $5 \% ;{ }^{* * *}$ significant at $1 \% . p$-values are presented in parentheses.

\section{Concluding Remarks}

In this study, we evaluate the effect of NRPS on the retirement sustainability in terms of both informal and formal labor supply and explore the regional differences in the effects of NRPS. Our results show that rural Western China has a more severe problem of "ceaseless toil", as of compared to the rest of the country. We found that receiving NRPS pension significantly improves the "ceaseless toil" 
situation, especially in Western China with the formal labor supply decreased by more than $7 \mathrm{~h}$ per week. This effect is not evident in the non-Western regions. This regional difference of the NRPS effect may be due to the income differences between the two regions. This result is in line with the findings of Bucciol et al. (2017) [27] that provision of pensions in European countries decreased the formal labor participation of people with lower income level. We thank an anonymous reviewer for his/her great insights in integrating this result. Furthermore, we find that increasing the amount of pension payment can significantly decrease the informal labor supply in the non-West region, implying the importance of increasing the amount of NRPS payment to provide stronger incentive to decrease labor participation [28-30]. The current level of NRPS payment is in general less than $10 \%$ of per capital rural income in China, which is significantly lower than the social pension in other countries (e.g., France, Italy, and Sweden [27], Germany [29], the United States [30], South Arica [31], Spain [32], Japan [33]).

In sum, our results show that the NRPS program improves retirement sustainability by alleviating the "ceaseless toil" situation of the Chinese elderly, and also suggest the need to increase the amount of NRPS payment and to develop region-specific pension programs in China. While our paper briefly reports the emerging regional disparity issue in the Chinese pension system, more rigorous econometric analysis should be conducted with additional waves of CHARLS to improve the statistical power of the study in the future. As the financial and social pressure coming from the current situation of the rural elderly exhaust, it is also important to consider other informal labor activities in addition to grandchildren care when searching for the determinants of NRPS. We thank an anonymous reviewer for his/her great insights on this point.

Author Contributions: Conceptualization, B.L., Y.Y.Z. and W.L.; Methodology, B.L. and Z.L.; Formal Analysis: B.L. and Z.L.; Writing, B.L., Z.L., Y.Y.Z., and W.L.

Funding: This work was supported by the National Natural Science Foundation of China (Project No. 71303049) and the Program for New Century Excellent Talents in Universities of Fujian Province (Project No. JAS14111).

Acknowledgments: The authors would like to thank four anonymous reviewers for their great comments and insights, and would also like to thank Ms. Joan Wang for her immense help in preparing this manuscript.

Conflicts of Interest: The authors declare no conflict of interest.

\section{References}

1. Bodie, Z.; Merton, R.C.; Samuelson, W.F. Labor supply flexibility and portfolio choice in a life cycle model. J. Econ. Dyn. Control 1992, 16, 427-449. [CrossRef]

2. Manoli, D.; Mullen, K.J.; Wagner, M. Policy variation, labor supply elasticities, and a structural model of retirement. Econ. Inq. 2015, 53, 1702-1717. [CrossRef] [PubMed]

3. Davis-Friedmann, D. Long Lives: Chinese Elderly and the Communist Revolution; Stanford University Press: Stanford, CA, USA, 1991.

4. Benjamin, D.; Brandt, L.; Fan, J.Z. Ceaseless Toil? Health and Labor of the Elderly in Rural China; William Davidson Institute Working Paper, No. 579; University of Michigan: Ann Arbor, MI, USA, 2003.

5. Pang, L.H.; Brauw, A.D.; Rozelle, S. Working Until You Drop: The Elderly of Rural China. China J. 2004, 52, 73-96.

6. Ning, M.X.; Gong, J.Q.; Zheng, X.H.; Zhuang, J. Does New Rural Pension Scheme Decrease Elderly Labor Supply? Evidence from CHARLS. China Econ. Rev. 2016, 41, 315-330. [CrossRef]

7. Lee, Y.J.; Xiao, Z. Children's Support for Elderly Parents in Urban and Rural China: Results from a National Survey. J. Cross-Cult. Gerontol. 1998, 13, 39-62. [CrossRef] [PubMed]

8. Cai, F.; Giles, J.; O'Keefe, P.; Wang, D. Old-Age Support in Rural China: Challenges and Prospects; World Bank: Washington, DC, USA, 2012.

9. Zimmer, Z.; Kwong, J. Family Size and Support of Older Adults in Urban and Rural China: Current Effects and Future Implications. Demography 2003, 40, 23-44. [CrossRef] [PubMed]

10. Shen, C.; Williamson, J.B. China's New Rural Pension Scheme: Can it be Improved? Int. J. Sociol. Soc. Policy 2010, 30, 239-250. [CrossRef] 
11. Zhu, H.; Walker, A. Pension system reform in China: Who gets what pensions? Soc. Policy Adm. 2018, 52, 1410-1424. [CrossRef]

12. Huang, H.W.; Zhan, J.T.; Cheng, C. The Impact of the New Rural Social Endowment Insurance Pension Income on the Rural Elderly Labor Supply. Chin. J. Popul. Sci. 2014, 2, 106-128.

13. Chen, Z.; Bengtsson, T.; Helgertz, J. Labor Supply Responses to New Rural Social Pension Insurance in China: A Regression Discontinuity Approach (No. 9360); Institute for the Study of Labor (IZA): Bonn, Germany, 2015.

14. Shu, L. The effect of the New Rural Social Pension Insurance program on the retirement and labor supply decision in China. J. Econ. Ageing 2018, 12, 135-150. [CrossRef]

15. $\mathrm{Xu}, \mathrm{H}$. Physical and mental health of Chinese grandparents caring for grandchildren and great-grandparents. Soc. Sci. Med. 2018, in press. [CrossRef] [PubMed]

16. Sun, Z. Explaining Regional Disparities of China's Economic growth: Geography, Policy and Infrastructure; University of California: Berkeley, CA, USA, 2013.

17. Song, Z.; Storesletten, K.; Wang, Y.; Zilibotti, F. Sharing High Growth Across Generations: Pensions and Demographic Transition in China. Am. Econ. J. Macroecon. 2015, 7, 1-39. [CrossRef]

18. Guo, Y. Pension Policy Reforms in China from 2009 to 2012. China J. Soc. Work 2014, 7, 237-246. [CrossRef]

19. Chang, H.H. Old Farmer Pension Program and Farm Succession: Evidence from a Population-Based Survey of Farm Households in Taiwan. Am. J. Agric. Econ. 2013, 95, 976-991. [CrossRef]

20. Imbens, G.W.; Lemieux, T. Regression Discontinuity Designs: A Guide to Practice. J. Econom. 2008, 142, 615-635. [CrossRef]

21. Currie, J.; Yelowitz, A. Are public housing projects good for kids? J. Public Econ. 2000, 75, 99-124. [CrossRef]

22. Dee, T.S.; Evans, W.N. Teen drinking and educational attainment: Evidence from two-sample instrumental variables estimates. J. Labor Econ. 2003, 21, 178-209. [CrossRef]

23. Fang, H.; Keane, M.P.; Silverman, D. Sources of advantageous selection: Evidence from the Medigap insurance market. J. Polit. Econ. 2008, 116, 303-350. [CrossRef]

24. Keane, M.; Stavrunova, O. Adverse selection, moral hazard and the demand for Medigap insurance. J. Econom. 2016, 190, 62-78. [CrossRef]

25. Mao, J.; Wang, D.; Bai, C. Poverty Reduction Policies and Local Government Public Spending: An Empirical Study Based on the 8-7 Plan. China Econ. Q. 2012, 11, 1365-1388.

26. Zhang, C. Pension and labor supply of rural elderly-based on the analysis of regression discontinuity method. World Econ. Pap. 2015, 6, 76-89.

27. Bucciol, A.; Cavalli, L.; Fedotenkov, I.; Pertile, P.; Polin, V.; Sartor, N.; Sommacal, A. A large scale OLG model for the analysis of the redistributive effects of policy reforms. Eur. J. Polit. Econ. 2017, 48, 104-127. [CrossRef]

28. Samwick, A.A. New evidence on pensions, social security, and the timing of retirement. J. Public Econ. 1998, 70, 207-236. [CrossRef]

29. Börsch-Supan, A. Incentive effects of social security on labor force participation: Evidence in Germany and across Europe. J. Public Econ. 2000, 78, 25-49. [CrossRef]

30. Blau, D.M.; Goodstein, R.M. Can social security explain trends in labor force participation of older men in the United States? J. Hum. Resour. 2010, 45, 328-363.

31. Posel, D.; James, A.F.; Frances, L. A Reconsideration of the Impact of Social Pension on Labor Supply in South Africa. Econ. Model. 2006, 23, 836-853. [CrossRef]

32. Martín, A.R.S. Endogenous retirement and public pension system reform in Spain. Econ. Model. 2010, 27, 336-349. [CrossRef]

33. Oshio, T.; Oishi, A.S.; Shimizutani, S. Social security reforms and labour force participation of the elderly in Japan. Jpn. Econ. Rev. 2011, 62, 248-271. [CrossRef]

(C) 2018 by the authors. Licensee MDPI, Basel, Switzerland. This article is an open access article distributed under the terms and conditions of the Creative Commons Attribution (CC BY) license (http:/ / creativecommons.org/licenses/by/4.0/). 